\title{
On two modalities of our secularity: anthropology's immanent frames
}

\section{Eduardo Dullo}

To cite this article: Eduardo Dullo (2021) On two modalities of our secularity: anthropology's immanent frames, Religion, 51:4, 533-550, DOI: 10.1080/0048721X.2021.1971497

To link to this article: https://doi.org/10.1080/0048721X.2021.1971497

册 Published online: 31 Aug 2021.

Submit your article to this journal

Џ Article views: 66

Q View related articles 5

View Crossmark data $\nearrow$

Citing articles: 4 View citing articles 지 


\title{
On two modalities of our secularity: anthropology's immanent frames
}

\author{
Eduardo Dullo \\ Universidade Federal do Rio Grande do Sul, Porto Alegre, Brazil
}

\begin{abstract}
How have anthropologists related to extraordinary or supernatural phenomena (the transcendent) in disciplinary definitions of religion and in the practice of social analysis? This text argues that the discipline's engagement with alterities that dispute our ontological secular conceptions makes evident its form of knowledge production. The central claim is that anthropology's secularity is not fixed and should be discussed as part of a historical process. I propose to analyse two modalities of secularity, which I term 'extinction' and 'captivity'. A second claim is that despite their differences, both modalities (re)produce to its academic and Euro-American audience anthropology's own secularity as a natural human condition. A third claim is that by recognising the characteristics of our discipline's secularity we may start to speak of a plurality of secular ontologies as a way to register the multiplicity of 'worldliness' that traditions and individuals may assume or call for.
\end{abstract}

\section{KEYWORDS}

Secularity; immanence; transcendence; supernatural; media; epistemology

\section{Introduction}

It is not unusual for anthropologists to find themselves in difficult situations in the course of fieldwork. A very prosaic occurrence is a feeling of discomfort with their subjects' relationship with the extraordinary, the marvellous, non-natural forces, more-thanhuman beings or what is perceived as going 'beyond' - a variety of occurrences that I am subsuming under the label of the transcendent for heuristic reasons. Both in personal and in epistemological terms, this situation has proved to be a challenging one. This ought to come as no surprise, as the vast majority of social and cultural anthropologists share a secular background acquired or further cemented in university, despite the fact that some have been raised in religious families or maintain their own faiths. Even more relevant than the personal dimension, the discipline itself is part of the development of a secular world. One might say: to argue that anthropology is a secular endeavour is nothing new. And yet, there is little discussion on anthropology's secularity as a distinct form of engagement with alterities that dispute our basic ontological conceptions and on how this secularity generates a particular form of knowledge production. Consequently, in this text, I explore the dynamic and diverse character of anthropology's secularity and reject the perception of a bounded, fixed and stable secularity for the discipline. As any 
secularity is part and parcel of a configuration of relations and concepts that change over time, there is no immutable secularity. Anthropology's secularity is no exception and there is much to gain by understanding its transformations through time. In order to do so, I will highlight two modalities (distinct configurations of a similar network of concepts), which I term 'Extinction' and 'Captivity' and will argue that despite their differences anthropology reproduces its own variegated secularity. In the conclusion, I will suggest that by recognising the characteristics of our discipline's secularity and how it has changed over the last couple of decades, we may open ourselves to new modalities of relationship to transcendence or even to epistemologies and ontologies that do not share the same network of concepts.

As an anthropologist from the Global South researching and teaching in the Brazilian context, I am quite often reminded that there is a triangulation in place: this academic discipline is part and parcel of a secular world that is not the same one in which I was raised. Nonetheless, I have learned to inhabit and share this secularity as a scholar. Thanks to this partial placement I would never hesitate to question: which secular world are we talking about when we discuss anthropology's secularity? To answer this question properly a second demarcation must also take place in the argument that follows: it will be restricted to a hegemonic Euro-American anthropology, as I will not be discussing the position of any other asymmetrically situated (with less prestige and/ or dominated) anthropologies from around the world. Hence, my approach here comes from a sense of (personal) alterity and (academic) belonging.

The matter of the anthropologist's religious belief (or lack thereof) is a frequent occurrence in anthropological texts. Sometimes it appears from a first-person perspective, as when Ewing was facing the 'taboo of going native' during research with Sufi saints in Pakistan and 'was the recipient of a dream sent by a saint' $(1994,574)$. Significantly, 'going native' was perceived as a risk not only to the personal life but to the professional one, as this would put the author at odds with anthropology's 'reductive atheism' (Ewing 1994, 572). Similarly, Lambek $(2014,3)$ argues that what anthropologists do while researching religion is better understood as 'benevolent skepticism'. I reckon on the existence of religiously inspired anthropologists as well as the existence of other possibilities within the same Euro-American secularity (the most relevant not being addressed here is the Romanticist undercurrent that crosses the history of the discipline ${ }^{1}$ ). For instance, Engelke $(2002,4)$ argues that for Evans-Pritchard and Victor Turner the inner life was so central that in some of their key works 'belief became an element of method'. What is crucial in those texts, Engelke suggests, is that both of them did not close their explanation, but sometimes left it slightly open.

The path I am taking is neither a discussion of personal lives (of religious or non-religious anthropologists) nor how anthropologists deal with the matter of faith in the context of their professional lives. Instead, I want to address the tacit built-in secularity of anthropological discourse. I argue that, there is a style of reasoning and a network of concepts that structure our production of knowledge, and moreover that network may take different configurations over time. Ewing $(1994,575)$ makes anthropology's tacit secularity quite explicit in this passage:

\footnotetext{
${ }^{1}$ As such, I will not be discussing in this text questions related to hermeneutics, meaning and understanding. Those subjects are too extensive to be properly dealt in this text.
} 
I conceptualized my defense of my distance from the sufis I met in terms of my goals as an anthropologist. I was also aware that, like Kondo, Peshkin, and other anthropologists, I clung to those goals to protect something thought of as my 'identity'.

There is something distinctive in anthropology's epistemic structure that can be discussed independently of personal religious affiliation or belonging. Farman $(2013,738)$ has consistently argued that 'in the West, the secular is, at this point, a distinctive formation in which one can identify internal notions, rules as well as, indeed, tensions and instabilities ... The secular has by now a tradition'. Anthropology is part and parcel of this discursive tradition and its distinctive secularity is pushed to a limit when attempting to grasp events that are not part of a secular and disenchanted world, events that are beyond or incompatible with our naturalistic ontology. This is not to say that religion and a certain sense of wonder are alien to Euro-American societies, just that there is a difference between dealing with some events anthropologically and theologically, for example (cf. Robbins 2006). Luhrmann, one of the authors that I will discuss in reference to the second modality of our discipline's secularity, has recently $(2018,80)$ recovered an illuminating passage from Meyer Fortes 'Preface' to an edited volume on sacrifice:

Being in part actors in their own religious systems, theologians must believe. Whereas anthropologists ... cannot but be agnostic if they want to achieve objectivity ... and objectivity, in the sense of analysis and description that are accepted as valid by reason ... is, surely, a sine qua non for all anthropological scholarship. (Fortes apud Luhrmann - original emphasis by Fortes) $)^{2}$

On the one hand, anthropologists can be and sometimes are followers of a religion in their own societies or can also be affected (as Favret-Saada [2012] and Ewing [1994]) by what happens to them during fieldwork, on the other hand, anthropologists are not theologians who work from inside their own religious traditions and systems. In what follows, my concern is directed to what 'reductive atheism' or 'benevolent skepticism' are and to the differences in the network of concepts one can find in the first and the second modality of secularity rather than to the personal life of each anthropologist. In other words, my goal is to highlight the epistemological difficulties that arise from intersubjective relationships and participation during fieldwork in an ontology that does not necessarily share anthropology's secular assumptions, in order to point out some consequences and possible directions for anthropology's secular future.

The decision to pursue a discussion of anthropology's secularity through some of the ways the discipline has been dealing with the transcendent is part of an analytic premise well deployed by Asad (2003) when he states that an anthropology of secularism might be best served by approaching the subject indirectly. When unexpected transcendent events happen in our fieldwork, it takes time and effort for both those involved and for the analyst (in this case anthropologist) to identify them as religious or to dismiss them as something else. In this vein, Keane $(2009,109)$ suggested that the anthropologist should ask those he does research with: 'what makes these respectively a vision, a prophetic experience, and a case of spirit possession rather than, say, fantasies, dreams,

\footnotetext{
${ }^{2}$ Despite these citations, I am not going to work with the categories of 'atheism' and 'agnosticism' as Ewing and Fortes did, for they appear to us as black boxes that makes one assume that what is being discussed is not only settled but also already known. What I would rather achieve here is an opening of those styles and explanations in order to better understand them.
} 
psychotic episodes, the effects of drugs or a sudden head injury?'. I wish to pursue two further questions: how does the anthropologist makes sense of these events? And how are those events are rendered into an account for a largely secular academic community?. In short, we need to scrutinise secular analysis 'at work'.

Bringing into discussion how Christian conversion (as in Paul's transformation on the road to Damascus) can be seen as a sudden rupture in the ordinary flow of social life, Robbins (2007) has pointed out how anthropology has a 'continuity thinking' style of reasoning that not only hindered the possibility of taking seriously the Christian radical break with the past on a personal and on a sociocultural level, but also prevented the discipline from coming to terms with other sudden and radical ruptures, such as revolutions (2007: 10). Thus, understanding how anthropology relates to the religious transcendent is a first step in a larger attempt to understand how the constitution of secular social explanations of the world excluded certain possibilities and had difficulty in integrating unexpected events into their accounts.

In the next section, I will argue that a central dimension in many anthropological concepts of religion is the immanence/transcendence duality and that this centrality is due to the genealogy of Euro-American secularity in which those concepts came into being. Subsequently, I will sketch how this network of concepts takes two distinct configurations or constitutes two modalities that I am calling Extinction and Captivity (of transcendence). The basic argument I want to pursue here is that anthropology's secularity has changed over time and this change can be grasped by the position and relation each modality grants to transcendence. Therefore, I am proposing a diachronic perception of these two modalities, despite an apparent coherence and similarity between them. In the Extinction modality, the anthropologist knows better: there is no such thing as people killing each other with witchcraft or ghosts and spirits dancing around the villages. Some things are real and some things are not; and the anthropologist is willing to act as the guardian of what is real and what can happen in the world in their narrative accounts of ethnographic phenomena. All 'wrong' beliefs are just standing in for something else and there must be a kinship, an economic or a political reason that will explain how things come to be conceived that way. Transcendence is extinguished as nothing more than an illusion and an immanent ontology in which a 'self-sufficient humanism' (Taylor 2007, 19-20) takes place. Alternatively, in the more recent Captivity modality, the anthropologist may not deal with the veracity of those happenings: they will take seriously claims from their research subjects and attempt to explain how they become real in the immanent frame - that is, how people come to believe in a particular transcendent idea or discuss the social effects of those practices (as in Keane's question 2009, 109). All those events (here captured by the idea of transcendence) are discussed not as something that comes from outside the secular ontological frame, they are kept under captivity of the immanent frame and only acquire existence as a consequence of human actions or as they affect and effect humans. In other words, instead of extinguishing these phenomena, in this second modality, we learn on how immanent human actions can breed the transcendence kept under captivity. The emergence of the Captivity modality does not result in the elimination of the Extinction modality, as they can and do coexist. The relation, I suggest, is closer to the one Foucault (1978, 106-108) identifies in the passage from the dispositif of alliance to the sexuality, that is, the Captivity modality has been built around and on the basis of the Extinction modality. 


\section{A network of concepts}

Asad (2003) and Taylor (2007) recognised, despite their differences, the trajectory of the secular as a transformation of its relation to another set of concepts. It would be a mistake to attempt to offer a positive description from within by ignoring where the limits are or how anthropology's secularity is produced via a removal of what is considered alien to itself. The secular is, therefore, not only established in relation to religion (which also varies according to historically defined relations of power and of knowledge) but is also constituted internally by a network of concepts that can, as any other configuration, change in structure.

Taylor's monumental book (2007) on the development of a secular age provides us with a detailed and comprehensive narrative of the change that includes an impersonal order, a self-sufficient humanism, and the coming of age of unbelief amidst the production of a localised perception of religion. Mahmood (2010) has rightly criticised those definitions as overly bounded by a North Atlantic (or Euro-American) narrative. However, this is in fact beneficial for the task at hand, as I am specifically addressing the Euro-American world. Since Asad's (1993) critique of the anthropological concept of religion due to its liberal, modern and Christian assumptions several others have examined the subject, exploring the imperialist production of 'religion' as a concept to be applied around the world and the production of traditions that would be rendered as 'religion' (e.g., Masuzawa 2005; Van Der Veer 2014).

The matter here, however, is less to produce a genealogy or a social history of the anthropological concept of religion and more to identify that anthropology's secularity is produced through and at the same time as these definitions of religion. The concepts of religion and secular are co-dependent and mutually constitutive. Hence, what I would like to do here is to point out some of these central concepts and focus on the transcendence/immanence axis to suggest that our discipline operates within the humanist immanent frame presented by Taylor (see also Kosky 2004). By doing this I am neither proposing to define the only aspect nor the most relevant one, but to highlight one of the relations that is constitutive of our discipline's secularity. In fact, Asad's book chapter (not the journal article ${ }^{3}$ ) on the concept of religion finishes $(1993,54)$ precisely with a footnote that quotes the same passage by Tambiah $(1990,6)$ that I reproduce in the next paragraph.

In his 1984 Morgan Lectures, Tambiah argued that

from a general anthropological standpoint the distinctive feature of religion as a generic concept lies not in the domain of belief and its 'rational accounting' of the workings of the universe, but in a special awareness of the transcendent, and the acts of symbolic communication that attempt to realise that awareness and live by its promptings.

Tambiah was not a lone voice. Following the already established distinction between Christian theology and the anthropological discourse on religion, Meyer (2016: 17) makes a contrast between the theologian Rudolf Otto and the anthropologist Robert R. Marett:

\footnotetext{
${ }^{3}$ Asad's journal article was published in 1983 and Tambiah's Morgan Lectures were delivered in 1984. It is relevant how Asad is concerned with including this passage as another anthropological attempt to conceptualise religion, but left out of the discussion the core aspect of transcendence.
} 
In distinction to Otto, who based his theory of religion on the existence of a transcendental force, Marett took as a starting-point the human being who reaches out to such a force from his or her position in the immanent, the here and now.

Meyer goes on to offer a revised reading of Marett's concern with 'awe' in order to investigate this awesome effect, or rather, to 'capture the wow' that constitutes the experience of religion. By formulating the matter in that way, Meyer is also revealing that what makes the 'general anthropological standpoint' visible is not taking the 'transcendental force' for granted but precisely the continuity of this concern with a beyond that is continuously affecting the immanence of the supposedly self-sufficient human world. Another definition that continues this line of thought (albeit a very reflexive one in that matter) is offered by Lambek (2014: 16), who contends that: 'One way to conceive of religion, then, is precisely as a sphere of human activity concerned with articulating (in thought and practice) the boundaries and relationship between immanence and transcendence'.

One of the effects of the constitution of the concept of religion by a secularised discipline is its production not only as something that has its limits and, therefore, can be localised, but also as something that is Other to ourselves. In the Euro-American tradition that Taylor (2007) scrutinises, and more precisely in the Catholic tradition, this has been particularly visible through miracles and apparitions: the intervention of an Other conceived as an outsider to this world which nonetheless affects it despite its internal natural laws. The removal of this Otherness into a transcendent position is precisely one of the effects of a secular production of religion, for 'antisecularists who advocate a fully Christian, Muslim, Jewish, Hindu, or Buddhist society' are attempting to overcome this position and establish the presence and immanence of the divinity in this world (Lambek 2014: 19). In brief, the establishment of a duality via the removal of God from this world led to the acceptance of the world as a natural entity, which could be seen objectively, the possibility of researching its internal laws and to the perception of human autonomy. As Gauchet (1997: 53) puts it, 'Not only does the separation of the deity allow humans to begin understanding the beyond, it also provides the initial foundations for making the world intelligible, independent of God'. Or, as Taylor (2011: 34) states:

And so the history of this term 'secular' in the West is complex and ambiguous. It starts off as one term in a dyad that distinguishes two dimensions of existence, identifying them by the particular type of time that is essential to each. But from the foundation of this clear distinction between the immanent and the transcendent, there develops another dyad, in which 'secular' refers to what pertains to a self-sufficient, immanent sphere and is contrasted with what relates to the transcendent realm (often identified as 'religious'). This binary can then undergo a further mutation, via a denial of the transcendent level, into a dyad in which one term refers to the real ('secular'), and the other refers to what is merely invented ('religious'); or where 'secular' refers to the institutions we really require to live in 'this world', and 'religious' or 'ecclesial' refers to optional accessories, which often disturb the course of thisworldly life. ${ }^{4}$

What makes anthropology peculiar in this matter is that it has always been looking for ways to grasp what is outside of its own societal and cultural frame. Anthropologists

${ }^{4}$ See also Asad (1993, 267). 
were, at the beginnings of the discipline, facing 'primitives', 'savages': those rendered not only outside anthropologists' progress and time (Fabian 1983) but also outside their own scientific rationality and religion. An intention to grasp how other human beings lived collectively followed the empirical and factual propositions that structured the Enlightened mind, as 'one should rather discover such regularity [of order, law, and reason] in the phenomena themselves, as the form of their immanent connection' (Cassirer $1951,9)$. The functionalist disposition to find social laws had as its premises the immanent connections of parts internal to a society, the relation of one element to another, and their relevance made evident as one could only grasp the local mode of thought by conceiving its context.

In its totalising aim, even the most unsuitable phenomena should be integrated into the complexity of the social, man-made, life. However, how can a secular discipline make room for a sense of wonder or for the unexpected in its explanation? The immanent secular condition is nothing less than an ontology and, as such, posed many difficulties for those attempting to deal with reasonings outside it. As Asad (2003, 194) states, the medieval world has been 'broken down by the modern doctrine of secularism into a duality: a world of self-authenticating things in which, we really live as social beings and a religious world that exists only in our imagination'. How can the anthropologist make this 'imaginary world', that is 'merely invented' and is viewed from the secularist standpoint as 'optional accessories', part and parcel of academic analysis?

In what follows I will further explore Lambek's $(2014,20)$ suggestion that 'immanence and transcendence can also stand for two ways in which anthropologists have apprehended religion, irrespective of how religion is manifest in a particular social formation' to argue that these two modalities of anthropology's secularity reproduce the immanent disposition sketched above each one in one direction. Extinction tends to reject the transcendent and find an immanent explanation for it; Captivity tends to explain how the subjects create themselves that perception of the transcendence, that is, they look for how humans produce the transcendent and make it real within the immanent frame. In highlighting this difference I want to stress not only that both modalities are fully secular but also that anthropology's secularity is neither bounded nor stable, but continuously changing.

\section{Extinction}

The first modality of our discipline's secularity is marked by a focus on how primitives' so-called 'wrong' or 'false' beliefs are, in fact, rational if understood within the man-made actions of the immanent frame, restricting transcendence to a specific place in the social life or rejecting it altogether. A closer look at young Gluckman's text ${ }^{5}$ will provide us with an ethnographical stance:

I can perhaps do this best by relating my own single mystical experience. About half-past two one morning I was walking along a lane which was reputed to be haunted. I had

\footnotetext{
${ }^{5}$ Despite displaying the same title as the PhD thesis from Oxford in 1936, the content is quite different. This is the Bachelor of Arts Thesis in Social Anthropology presented at the University of Witwatersrand. It was made available by the University at: http://wiredspace.wits.ac.za/handle/10539/16882.
} 
been discussing the supernatural, was physically tired and mentally depressed. As a natural rather than a supernatural consequence of these facts, I suddenly saw hordes of dancing skeletons and ghosts, for me an unusual, though strangely not a discommoding, spectacle. All at once I seemed to sense a presence above and around me, an almost physical power in which I could rest. The bizarre figures all vanished; I had, so to speak, found peace in God. (Gluckman 1934, 41)

What a discussion that might have been if it weren't for Gluckman's phlegmatic spirit! Instead, the so-called mystical experience is understood as a consequence of a combination of circumstances: he might have been influenced by the subject of his discussion with his research subjects and was experiencing a physical and mental - not to mention emotional - fatigue. Consequently, Gluckman explains away not only his vision but also the transcendental presence in which he found peace. The next paragraph $(1934,41)$ make this even more clear:

Here is the raw matrix of religion, the sense of powers working around us. And now, to distinguish the religious sense from the scientist's sense of these powers, one must refer to the fact that most men (so called civilised as well as primitive) fail to distinguish between the causes of their sensations and the emotions evoked by the sensations themselves.

The naturalistic language of cause and effect is well suited to the Enlightenment disposition laid down by Cassirer (1951) and makes room for a scientific and rational explanation of first-person description. In fact, as Luhrmann recently argued $(2018,79)$ : 'most anthropologists have insisted that God, or the gods, cannot be understood anthropologically except through an explicit decision to disavow the idea that such beliefs might be true'. This is the case with Gluckman. Passages like this one contribute to the perception of the discipline as sustaining a 'reductive atheism' or at least bound the anthropology's secularity in this modality to a negation of the transcendent. This secular sensibility was stronger during the first half of the twentieth century, but has persisted until the present. Another scholar who became aware of the degree to which he was embedded in a secular disposition and sensibility during his research was Pierre Bourdieu. In a dialogue he stated:

The other thing that I found out through self-analysis, armed with the history of the discipline ... is that that period, from Renan to the 1914 war, was dominated by the constitution of the social sciences against religion, and that in the unconscious of our discipline lies this negation, this original refusal. I discovered within my own mind all the mutilations I inherited from this secular tradition, reinforced by my science's implicit assumptions. (Bourdieu and Maître 1994, XV)

These negations are constitutive of Extinction, in its rejection of what is taken to be the 'supernatural', 'religious' or 'transcendent'. And yet, if one does not want to give much credence to Gluckman's youthful opinions, perhaps a 1965 Lecture can provide a more experienced view. On this occasion, Gluckman was comparing moral crises and the allocation of responsibilities among the 'primitives' and in 'secular' society. In either case, the individual subject was mostly unaware of the sociological reasons for such moral crises, but the former responded in quite distinct terms:

When they resort to divination to obtain further knowledge it may be, as Forde stressed in his Frazer lecture, because of the limits of their technical knowledge. But we have still to 
explain why this uncertainty and ignorance are interpreted so strongly in moral terms. (Gluckman 2014, 371)

Hence, Gluckman (2014) stresses the existence of a conflict between duty and the good in the agnatic kinship system of the South-eastern Bantu social structure under analysis. His argument is that the accusations of witchcraft and the magical solutions found were just a particular way of dealing with what was generated by a non-mystical source. At the end of his lecture, Gluckman compares the origin of moral crises with another kinship situation, where a family business does not grow as fast as the family who runs the company, generating envy and discomfort by not integrating all family members (including in-laws) into desired positions. This final comparison makes even more evident that the source of the problem is the gap between individual actions (and the desirability of the good) and structural contradictions that are beyond their knowledge. Solutions to moral crises can be either magical or secular. Gluckman conceives of these solutions as morally equivalent and stresses the illusionary character of the primitive mind. Anyone from his own society 'would be regarded as mentally ill' $(2014,372)$ if they related their misfortunes to occult ideas.

The surprise would be, then, his question over the reasons for the 'primitives' interpreting the facts in moral terms. As an anthropologist working with the notions of duty and good, Gluckman is aware of Durkheim's (2004) definition of a moral fact as a duality of obligations (duty) and desirability (good) - what conducts Durkheim's argument to claim a proximity, via this same duality, between the moral and the sacred (as this is also conceived as an object of taboo and something that is desired). One can also find in Durkheim a similar gap between the immanent individual action and the transcendent order of society. In his attempt to define the singularity of the moral fact from a sociological position, Durkheim had to confront positions that established God as its original source. In his construction of the argument that it is 'society that is the source of a transcendent authority and of ideals of the good' (Watts Miller 1998, 75), Durkheim (2010, 25) stated:

In the world of experience I know of only one being that possesses a richer and more complex moral reality than our own, and that is the collective being. I am mistaken; there is another being which could play the same part, and that is the Divinity. Between God and society lies the choice. (...) I can only add that I myself am quite indifferent to this choice, since I see in the Divinity only society transfigured and symbolically expressed.

In his argument, society came to be at the same time made by immanent individual actions and a reality beyond the conscience of those individuals. The notion of the good had its source in society, a man-made transcendent reality. By claiming his indifference to the choice between God and society, Durkheim was pointing to the fact that they were both the creation of human collective actions. Society is, in this sense, a secular version of God: it is a secular transcendence. Lambek has an alternative reading (2014, 21 ), but also points to this change of perspective between transcendence and immanence as he states that 'for Durkheim, religion could be transcendent from the perspective of the members of a society but immanent to that society from the perspective of the sociologist standing outside it'. In both readings (Lambek's and mine) what remains is that from the sociologist's perspective there is an extinction of transcendence - that it only exists from the mistaken perspective of the members of that society who are not fully aware of their collective responsibility in producing that perception. 


\section{Captivity}

At the turn of the 1970s a new sensibility towards the collectivities researched by anthropologists was emerging, one that is still growing and evolving in our discipline. I have suggested elsewhere (Dullo 2016) a possible genealogy for the 'taking seriously' jargon in contemporary anthropology. ${ }^{6}$ There, I addressed the acknowledgment of people's reflexivity and capacity for social critique as a consequence of postcolonial criticism, and, more recently, the ontological turn. I also argued that not every subject could be taken seriously in the same way and that, until very recently, Christianity remained a more 'repugnant other' (Harding 1991). The present discussion gives me the opportunity to face a sensibility that was changing underneath those almost independent movements, mostly derived from the modern value of toleration and its romanticist inflection (i.e., a willingness to accept others' belief if they are sincere about it (e.g., Berlin 1999, 9)). To convey this sensibility I am drawing on two central texts: Favret-Saada's Deadly Words (1980) as a marker of the turning point and Tanya Luhrmann's work $(2007,2012)$ as a more recent position encompassing a wide range of authors who focus on the mediation of the transcendent (e.g., Keane [2009] and Meyer [2016]).

Favret-Saada's book (1980) offers its readers a very different sensibility from Gluckman's lecture within the short span of a decade. ${ }^{7}$ Researching accusations or, rather, rumours of witchcraft in the French countryside, Favret-Saada found that peasants were considered 'superstitious', 'credulous' and 'backward'. ${ }^{8}$ The whole opening of the book is dedicated to confronting this secular sensibility rooted in 'journalists' and 'folklorists', but also present in almost everyone with whom she could interact (doctors and vets are introduced as 'curators of objective knowledge' $(1980,6))$. Even Catholic priests did not take witchcraft accusations seriously as, according to Favret-Saada, their elitism usually prevented them from considering peasants worthy of the Devil's attention. Favret-Saada appears engaged with the 'moral narrative of secularism' (Keane 2013), one in which the obligatory claims (how one ought to be and live) for human agency, natural laws, and the impossibility of mystical and occult influences are dismissed in order to act as an anthropologist researching reasonable subjects in Western Europe. As she elaborates in another piece $\left(1990,2012^{9}\right)$, at that historical moment (mid-1960s until the end of the 1970s),

[t]he act of speech itself, however, is magicked away and native discourse is reduced to its end-product - acts of speech mistaken for propositions. Symbolic activity, then, is little more than false propositions. As we see, all these confusions circle around one common point: the disqualification of native speech and the promotion of that of the ethnographer

\footnotetext{
${ }^{6}$ I call this a jargon because there is no single agreement on its definition. The most precise text on defining what is meant by 'taking seriously' is, very likely, Viveiros de Castro's The relative native (2013 [2002]). As I mentioned above, I am not analysing those who are strongly influenced by a (neo)romanticist undercurrent (as Viveiros de Castro's theoretical position is read by some - e.g., Duarte 2015).

${ }^{7}$ Gluckman's lecture was delivered in 1965 and the french original edition of Favret-Saada's book is from 1977.

${ }^{8}$ Favret-Saada does not discuss at length how their Catholicism had an impact in that setting and affected the manner they dealt with those rumours of witchcraft.

${ }^{9}$ Two English versions are available, one published in 1990 (following a presentation at the 1987's AAA Conference) and a more recent translation in 2012. A discussion of the differences of both texts would be instructive, but will be left to another occasion. For now, it is worth highlighting the change in a particular world: native discourse was first 'discounted' $(1990,191)$ and then $(2012,438)$, is 'magicked away'.
} 
- whose activity seems to consist of making a detour through Africa in order to verify that only he holds ... we're not sure what, a set of vaguely related notions that, for him, apparently equal the truth. $(2012,438-439)$

This is a remarkable transformation from the Extinction modality where the anthropological identity was endangered by 'going native' and accepting another explanation of what is and is not possible. ${ }^{10}$ The central point now is the claim that to be an anthropologist one must be the one (even if the only one) to take those subjects seriously - because failure to do so would would erase anthropology's distinctiveness from other secular actors under criticism. Favret-Saada's second chapter has this astounding opening $(1980,13)$ :

There is one precept of British anthropology - perhaps the only one in the name of which I can call myself an ethnographer - by which the native is always right, if he leads the investigator in unexpected directions.

And yet, if my first argument is to highlight this difference from the Extinction modality, my second one is that Deadly Words is not so distant from previous discussions to constitute a radical break with our discipline's secularity: it represents another modality, a change of emphasis and relation in the same network of concepts. A way of perceiving this argument is by noting how she places a footnote at the end of that sentence in which she mentions Evans-Pritchard as her inspiration (for he analysed witchcraft in Zandeland and cattle in Nuerland). We might speculate that Favret-Saada is saying that the anthropologist should be interested in what constitutes the native's reality, no matter how wondrous or unexpected that might be - or rather, precisely because it is unexpected. $^{11}$

What Favret-Saada was attempting to do was to distance herself from the kinds of propositions subsumed under the 'they believe that' sensibility to focus instead on the relations enabled by that same discourse. Consequently, Favret-Saada's argument is in line with the elaboration made by Taylor (2007) that in the Euro-American secular age religion is not the default, but something that is perceived as supplemental to rational causal explanation. 'In short, unlike a Zande who in all circumstances only has the choice between witchcraft and sorcery - two concepts which in the Bocage are totally indistinguishable - the countryman knows perfectly well that there are explanations of another kind' (Favret-Saada 1980, 14). There appears to be an important difference between the peasant and the 'primitive' Zande: the former lives in a secular social order and is aware of that, hence, operating within the witchcraft discourse is a conscious decision (although it is not perceived as freely chosen, but imposed on the person by himself and others) that segregates the person from that same social order and brings him into a 'state of secrecy'.

From this moment on, the anthropological questions posed in Deadly Words might turn into more routine discussions from authors writing within an Extinction modality: 'What is important, then, is less to decode what is said than to understand who is

\footnotetext{
${ }^{10}$ The contrast is evident with Ewing $(1994,577)$ in which she states her discomfort with 'a sufi explanatory model. [in which] According to this model, a sufi may communicate with a disciple through a dream; such a dream, therefore, has its sources in an intentionality external to the dreamer, that of the sufi saint who has sent the dream. If I accept such a proposition, there are implications for my experience of causality and for my place in a network of human relationships that are incompatible with the secularized world of the Western social scientist and the psychoanalyst.'

${ }^{11}$ This proposition opens itself to the importance of the unexpected during fieldwork but also to the expectation of finding the unexpected; that is, to find a group to whom very well established anthropological truths do not apply.
} 
speaking and to whom' (Favret-Saada 1980, 14). This is not about meaning, but rather about relations. Thus, when research deals with secrecy and a secret network, there is no room for someone who is not addressed, and, since 'spoken words are power, not knowledge or information' $(1980,9)$, one is only addressed if they are taken to have been caught or catching, that is, in a power relationship. Favret-Saada's acknowledgment of the power of words could only happen through a modification of her own relationship towards her interlocutors and their discourse from inside the immanent secular order to the point that she produces another modality of this same order, one in which the transcendent or the occult-mystical influence can be understood by the power of (human) words.

The point I want to make here is that despite the difference in sensibility towards the Other generated by the 'taking seriously' stance, Deadly Words is not a rupture, but a transformation of the same network of concepts, and as such displays a continuity with previous secular positions. Favret-Saada's explanation is not an attempt to boldly claim that words can kill as surely as a bullet, but an argument for the capacity of symbolisation from those 'simple-minded backward countrymen' in dealing with misfortunes. In this particular sense, it is not very far from Evans-Pritchard's argument concerning the rationality of the Zande's mode of thought. What makes it appear very different is a change in the sensibility towards what lies beyond Euro-American secular assumptions, willing to accept the reality of the transcendent but only insofar as this is produced within an immanent frame - including, in this particular case, that the reality of witchcraft is present within modern secular France.

Let's take a closer look at Luhrmann's work $(2007,2012)$ with Christians in the United States who claim to be talking to God. As in Favret-Saada's text, one of the propositions is to defend their reasonableness and to make clear that they are not delusional. It is interesting that once the secularisation narrative of the end of religion in the civilised world proved a failure, the politically crucial anthropological claim once made for 'primitives' is now being made for Euro-American fellows. In Luhrmann's research, however, the question changes from the reasons for that specific way of dealing with an unexplained crisis to how those people came to talk to God or, rather, how they learned to perceive ordinary events as related to God.

Anthropologists are taught as students to seek to understand before we judge. (...) And so I will not presume to know ultimate reality. I will not judge whether God is or is not present to the people I came to know. Yet I believe that if God speaks, God's voice is heard through human minds constrained by their biology and shaped by their social community, and I believe that as a psychologically trained anthropologist, I can say something about those constraints and their social shaping. (Luhrmann 2012, xxiv)

Thus, Luhrmann's attention is focused on the development of several techniques or skills that allow those Christians to understand that there is 'an external being's presence in [their] mind', to perceive the 'signs of God's intentional presence in their lives' (2007, 89-90), and to learn that God is present even when they do not notice (2007, 93-94). In this sense, Luhrmann's work can be taken as an example of the change in anthropological sensibility that produced a change in theory. Moving away from the veracity of people's beliefs and focusing on practices of mediation, the anthropological concept of religion has taken a significant material turn. Keane's (2009) work, as well as the 
whole material turn (Engelke 2010) in which Meyer's (2016; Meyer and Houtman 2012) propositions are central can be taken as part of this movement that composes the Captivity modality. For instance, Meyer $(2016,8)$ asks:

How to address [transcendental] phenomena as anthropologists of religion? How, in other words, to develop an approach that allows us to 'capture the 'wow' without either taking for granted the existence of the god or 'beyond' to which the sense of 'wow' refers, or dismissing it as an irrational illusion?.

The answer, interestingly, is quite similar to Luhrmann's in the sense that one should try to grasp how this 'wow' is created by immanent actions, as there are 'standardized procedures' which 'generate in religious practitioners - over and over again - a sense of wonder and amazement' $(2016,18)$. Meyer's approaches part ways from Luhrmann with the inclusion of the 'sensational forms' and the materiality of the objects in producing this sensation.

Enough has been said about Luhrmann's book to highlight the modern, individualistic character of this particular experience of God. ${ }^{12}$ What I want to stress here is that those Christians, like Favret-Saada's peasants, are also taken to live inside a secular world. This is not only because they live in the United States, but primarily because their relation to religion is structured via this same immanent secularity and their creation of that experience is made via modern methods. The crucial point is the persistence of the anthropological perception of a duality: the transcendence of the Divinity and the immanent world from which both the anthropologist and the believers act; but while the latter learns how to reach this transcendent reality, ${ }^{13}$ the former is not attempting to reach anything beyond its own immanent-frame. This is the common secular ground between Extinction and Captivity.

In sum, the anthropologist is someone who does not dismiss people's claims outright, instead of approaching them in good faith to discover how it came to be that God talked to them. It comes as no surprise then, that Luhrmann (2018) has recently resurrected Fortes' commentary on disciplinary agnosticism. But this is not all. The anthropologist also inhabits this same immanent secular order and is, therefore, limited in the explanation of and access to transcendence. The possibility left for a secular anthropology is to stress how someone acquires the capacity to distinguish God's voice from another will or desire that he or she may have. It is not possible to assert if God does, indeed, talk to those fellows, but it is possible for a social scientist to describe the human action that made God real for them by pursuing an understanding of the ways those people 'train themselves' to interpret certain evidence as God's presence. In doing this, the anthropologist is neither accepting God as real nor negating their claim; Luhrmann is describing 'the human side of that relationship, the way humans reach for God' (2012, xxiv), and in succeeding in her task she also stresses the man-made character of this God:

\footnotetext{
${ }^{12}$ See also Gauchet $(1997,64-65)$ : 'As transcendence unfolded and the two kingdoms slowly drifted apart, interiority gradually gained enough momentum, to begin contesting the hierarchical principle. The more God was separated from us by his infinite nature, the more the relationship with him tended to become purely personal, to the point of excluding any institutional mediation. By becoming absolute, the divine subject could only find a legitimate terrestrial guarantor within inner presence. So initial interiority directly turned into religious individuality'.

${ }^{13}$ In effect, people train the mind in such a way that they experience part of their mind as the presence of God. They learn to reinterpret the familiar experiences of their own minds and bodies as not being their own at all-but God's. They learn to identify some thoughts as God's voice ... '. (Luhrmann 2012, xxi - added emphasis)
} 
'They allow the God they learn to experience in their minds to persuade them that an external God looks after them and loves them unconditionally' (Luhrmann 2012, xxi).

\section{Conclusion}

In this article, I sought to avoid a stable and bounded perception of what constitutes anthropology's secularity. This way of posing the matter runs the risk of producing a misunderstanding, which I wish to prevent. In sketching two modalities of the Euro-American anthropology's secularity by mobilising certain texts and authors, I offered a division that could suggest that each modality corresponds to one historical period. That would be untrue: what I want to make clear is that I presented (albeit very quickly) the emergence and development of each modality in its own moment within anthropology and that the emergence of Captivity neither invalidates nor overcomes the existence of Extinction. That is precisely what was meant by calling them modalities: the fact that both share the same network of concepts and respond to a similar epistemic structure. Captivity could only happen because Extinction was already in place and because one specific axis of that conceptual network is modified, that is, the relationship between transcendence and immanence. In Captivity, anthropologists' are concerned with the ways human agency is taken to produce the immanence of the transcendence instead of extinguishing transcendence from the start as nothing more than an illusion or false beliefs from 'savages' or 'primitives'. In doing this, anthropology partially reverses the trajectory traced by Taylor $(2011,34)$, which may give the false impression of being less secularised. There is certainly a change in the sensibility surrounding anthropology's secularity that corresponds to this passage from the Extinction to the Captivity, and at the moment, the latter is the predominant one. However, I suggest that this change in our sensibility does not cancel out Extinction, but rather places it in an encompassed and subordinated position.

The main argument, then, is that even when discussing Euro-American anthropology's secularity there is no one unified, stable and bounded definition, but a range of modalities that vary in time and may not be limited to the two sketched here. A secondary argument is that both are equally real and constitutive of anthropology's secularity. It would be a mistake to assume that anthropology is less secular in the second modality than in the first. ${ }^{14}$ This is true even when considering other interesting suggestions, such as Bialecki's (2014) Latourian take on Luhrmann's book and Keane's mediation (2014). Bialecki questions the mediation as a reduction (as in Captivity) of God (or the transcendent) to its humane production to the point that God and human subjects cannot be taken seriously as 'being ontologically coequal actors' (2014, 37-38), and, at the same time reinforces this secular view by making God pragmatically real in a flat immanent ontology. It thus still operates within the immanence/transcendence

\footnotetext{
${ }^{14} \mathrm{~A}$ fascinating conversation between Susan Harding and Mayanthi Fernando from April 2020 makes this point very clear. While discussing the difficulty of asserting what happened to them in the field and the existence of supernatural phenomena, Harding argues for the anthropologist to keep the guardian stance towards secularity while not extinguishing those phenomena from the anthropological account or, in her own words: "We might be accused of abandoning our guard posts and getting religion, but I wonder if there's a way we could make this case - for the agency of more-than-humans - without threatening the secularity of our knowledge practices.' (https://tif.ssrc.org/2020/04/ 27/fernando-and-harding/ - Accessed in 1st of April 2021) Unfortunately this conversation happened after this piece was already written and I could only give it this brief mention.
} 
duality, even as it transforms it. One of the aims of this text was to make this very point: in Captivity there is another configuration of the same networks of concepts in which self-sufficient humanism is still responsible for the production of 'everything there is', even if this means the production of transcendence from immanent human action.

I am going to make two entangled further suggestions. The first is that in both modalities social anthropology has been describing the experiences of their subjects via this immanent man-made secular frame in a manner that (re)produces its own network of concepts and its modalities of secularity as a natural human condition to its academic and Euro-American audience. The second is that in this exercise of recognising the immanent character of our discipline's secularity we may open anthropology to the recognition that other societies are not constituted by the same network of concepts as our own.

If we accept that anthropologists invent a culture for their subjects (sensu Wagner 1981) and that they translate those experiences into their own concepts and languages, they also invent a culture or a social analysis from their own secular perspective. In a similar manner to the Western production of a natural religion (Asad 1993, 40-43), the duality of immanence and transcendence (as in the supernatural) is very often assumed by the anthropologist as constitutive of everyone's experience. In the first modality, the possibility of transcendence is just dismissed (Extinction); in the second one, in which the native's claim for the possibility of the presence of a transcendence is taken seriously, the anthropologist brings it back within the humanist immanent order in their attempt to explain it (Captivity). As a consequence, in both of these modalities of anthropology's secularity, the discipline not only renders its own version of the secular condition into accounts of other people's lives but also - and this is crucial - produces more secularity to its audience, reinforcing its own system in the process.

Aware of this disposition, anthropologists could engage the reflexive attitude that they are trained to master, and realise that the Euro-American genealogy is not the only mode of being secular. Perhaps there are other networks of concepts that do not lean on the immanence/transcendence duality. One must not expect that outside the North Atlantic world one needs to go through the same process of secularisation in order to finally become secular. This is how I understand Furani's $(2014,18)$ claim for us 'to speak of a plurality of secular ontologies' as a way to register the multiplicity of 'worldliness' that traditions and individuals may assume or call for. To quote Douglas (apud Larsen 2014, 140-141):

When we look more closely at our information we find plenty of secular savages. Indeed, in certain tribal places there is a notable lack of interest in the supernatural. God is not suddenly dead with Western civilization. Science has not delivered the coup de grace. Anthropologists should really think before they subscribe to this particular fantasy about the difference between Us and Them.

The central point in this suggestion, to paraphrase Lambek $(2014,14)$, is not to purge anthropology of its secularity, but to recognise its particular modalities and how this compares to alternative concepts from other traditions and ontologies. A possible starting point could be to change the structure of our network of concepts. Instead of the immanent/transcendent duality and human control over how to make God real, anthropologists could give more room to another aspect that matters in those religious 
experience and that have been present all along: the element of surprise, the unexpectedness that is recurrent in miracles, dreams, prophecies, and revelations. Hence, I consider Bialecki's $(2014,42)$ criticism of Luhrmann when stating that 'Surprise is important because it helps address one of the chief issues that Luhrmann's believers struggle with: creating a sensation that they are interacting with an autonomous being with an independent will'. By trying to make sense of the divine dream of a 3-year old Muslim girl in Egypt, Mittermaier $(2012,248)$ suggests a similar move as the one I am advocating here by asking us to pay attention to 'stories of visitational and divinely inspired dreams' as they 'can be profound reminders not only of the unpredictability of divine intervention but also of the contingency of life itself. To continue Robbins's $(2007,10)$ theopolitical question that connects Christianity and revolution, we could remember Carl Schmitt's Political Theology in which - against the liberal enlightened attempt to control the exception $(2005,14)$ - he states not only that 'The exception in jurisprudence is analogous to the miracle in theology' $(2005,36)$, but also that 'the precise details of an emergency cannot be anticipated' $(2005,6)$. This particular connection between an anthropology of sovereignty and an anthropology of religion may take us far - not from the secular, but into the unexpected.

\section{Acknowledgements}

It was a pleasure to discuss a first version of this piece with all the participants of the Wenner-Gren Workshop Anthropology Within and Without the Secular Condition at CUNY in 2017. Khaled Furani and Joel Robbins, the organisers, provided me with invaluable insights and feedback. I also benefitted greatly from the Religion anonymous reviewers, Luiz Fernando Dias Duarte, Naomi Haynes, Corinna Howland, and Katerina Hatzikidi's comments. It was a pleasure to have Michael Stausberg's terrific editorial suggestions, which helped me offer this polished final version.

\section{Disclosure statement}

No potential conflict of interest was reported by the author(s).

\section{Notes on contributor}

Eduardo Dullo is an Associate Professor at the Anthropology Department of the Federal University of Rio Grande do Sul, where he is also the Director of the Religious Studies Centre (Núcleo de Estudos da Religião) and editor of Debates do NER. He has been researching the formation of Brazilian secularity over the 20th Century and the entanglement of religion, politics, and educational projects. His current research is dedicated to comparison of Brazilian and Turkish receptions of the French ideal of laicité.

\section{ORCID}

Eduardo Dullo (D) http://orcid.org/orcid.org/0000-0003-3793-7406

\section{References}

Asad, T. 1993. Genealogies of Religion: Disciplines and Reasons of Power in Christianity and Islam. Baltimore: Johns Hopkins University Press. 
Asad, T. 2003. Formations of the Secular: Christianity, Islam, Modenity. Stanford: Stanford University Press.

Berlin, I. 1999. The Roots of Romanticism. Edited by Henry Hardy. Princeton: Princeton University Press.

Bialecki, J. 2014. "Does God Exist in Methodological Atheism? On Tanya Luhrmann's When God Talks Back and Bruno Latour." Anthropology of Consciousness 25 (1): 32-52. doi:10.1111/anoc. 12017.

Bourdieu, P., and J. Maître. 1994. “Avant-propos Dialogué.” In L'autobiographie D’un Paranoïaque, edited by Jacques Maître, v-xiii. Paris: Anthropos.

Cassirer, E. 1951. The Philosophy of the Enlightenment. Princeton: Princeton University Press.

Duarte, L. F. 2015. "Romanticism and Holism in the Anthropology of the West (Revisiting Bergson's Paradox).” Anthropological Theory 15 (2): 179-199. doi:10.1177/1463499614567690.

Dullo, E. 2016. “Seriously Enough? Describing or Analysing the Native(s)'s Point of View." In After the Crisis: Anthropological Thought, Neoliberalism and the Aftermath, edited by James G. Carrier, 133-153. London: Routledge.

Durkheim, É. 2010. "The Determination of the Moral Facts.” In Sociology and Philosophy, 16-31. London: Routledge.

Engelke, M. 2002. "The Problem of Belief: Evans-Pritchard and Victor Turner on 'the Inner Life'.” Anthropology Today 18 (6): 3-8. doi:10.1111/1467-8322.00146.

Engelke, M. 2010. "Religion and the Media Turn: a Review Essay." American Ethnologist 37 (2): 371-379. doi:10.1111/j.1548-1425.2010.01261.x.

Ewing, K. 1994. "Dreams from a Saint: Anthropological Atheism and the Temptation to Believe." American Anthropologist 96 (3): 571-583. Accessed April 22, 2021, from http://www.jstor.org/ stable/682301.

Fabian, J. 1983. Time and the Other: How Anthropology Makes its Object. New York: Columbia University Press.

Farman, A. 2013. "Speculative Matter: Secular Bodies, Minds, and Persons." Cultural Anthropology 28 (4): 737-759. doi:10.1111/cuan.12035.

Favret-Saada, J. [1980] 1977. Deadly Words: Witchcraft in the Bocage. Cambridge: Cambridge University Press.

Favret-Saada, J. 2012. “Being Affected.” HAU: Journal of Ethnographic Theory 2 (1): 435-445. doi:10.14318/hau2.1.019.

Foucault, M. 1978. The History of Sexuality: Volume I: An Introduction. New York: Pantheon Books.

Furani, K. 2014. “Is There a Postsecular?" Journal of the American Academy of Religion 83 (1): 126. doi:10.1093/jaarel/lfu082.

Gauchet, M. 1997. The Disenchantment of the World. A Political History of Religion. Princeton: Princeton University Press.

Gluckman, M. 1934. "The Realm of the Supernatural Among the South Eastern Bantu: A Study of the Practical Working of Religions and Magic." B.A. Thesis, The University of Witwatersrand.

Gluckman, M. [2014] 1972. "Moral Crises: Magical and Secular Solutions. The Marett Lectures, 1964 and 1965". Reprint." HAU: Journal of Ethnographic Theory 4 (2): 369-405. doi:10. 14318/hau4.2.025.

Harding, S. 1991. "Representing Fundamentalism: The Problem of the Repugnant Other." Social Research 58 (2): 373-393. Accessed April 22, 2021, from http://www.jstor.org/stable/40970650.

Keane, W. 2009. "The Evidence of the Senses and the Materiality of Religion." In The Objects of Evidence, edited by Matthew Engelke, 105-121. London: Wiley-Blackwell and Royal Anthropological Institute.

Keane, W. 2013. "Secularism as a Moral Narrative of Modernity." Transit: Europäische Revue (43): 159-170. Accessed April 22, 2021, from https://sites.lsa.umich.edu/webbkeane/wp-content/ uploads/sites/128/2014/07/secularism_moral.pdf.

Kosky, J. L. 2004. "The Birth of Modern Philosophy and the Death of Transcendence." In Transcendence: Philosophy, Literature, and Theology Approach the Beyond, edited by Regina Schwartz, 13-29. New York: Routledge. 
Lambek, M. 2014. “What is 'Religion' for Anthropology? And What has Anthropology Brought to 'Religion'?” In A Companion to the Anthropology of Religion, edited by Janice Boddy, and Michael Lambek, 1-32. Oxford: Wiley.

Larsen, T. 2014. The Slain God. Anthropologists and the Christian Faith. Oxford: Oxford University Press.

Luhrmann, T. M. 2007. "How do you Learn to Know That it is God who Speaks?" In Learning Religion: Anthropological Approaches, edited by David Berliner, and Ramon Sarró, 83-102. Oxford: Berghahn Books.

Luhrmann, T. M. 2012. When God Talks Back. New York: Alfred A. Knopf.

Luhrmann, T. M. 2018. “The Real Ontological Challenge.” HAU: Journal of Ethnographic Theory 8 (1-2): 79-82. doi:10.1086/698408.

Mahmood, S. 2010. “Can Secularism be Other-Wise?” In Varieties of Secularism in a Secular Age, edited by Michael Warner, Jonathan VanAntwerpen, and Craig Calhoun, 282-299. Cambridge: Harvard University Press.

Masuzawa, T. 2005. The Invention of World Religions: Or, How European Universalism Was Preserved in the Language of Pluralism. Chicago: University of Chicago Press.

Meyer, B. 2016. "How to Capture the 'Wow': R.R. Marett's Notion of Awe and the Study of Religion." Journal of the Royal Anthropological Institute 22: 7-26. doi:10.1111/1467-9655.12331.

Meyer, B., and D. Houtman. 2012. "Material Religion - How Things Matter." In Things: Religion and the Question of Materiality, edited by Dick Houtman, and Birgit Meyer, 1-23. New York: Fordham UP.

Mittermaier, A. 2012. "Dreams from Elsewhere: Muslim Subjectivities Beyond the Trope of SelfCultivation." Journal of the Royal Anthropological Institute 18 (2): 247-265. doi:10.1111/j.14679655.2012.01742.x.

Robbins, J. 2006. “Anthropology and Theology: An Awkward Relationship.” Anthropological Quarterly 79 (2): 285-294. doi:10.1353/anq.2006.0025.

Robbins, J. 2007. "Continuity Thinking and the Problem of Christian Culture: Belief, Time, and the Anthropology of Christianity." Current Anthropology 48 (1): 5-38. doi:10.1086/508690.

Schmitt, C. 2005. Political Theology. Chicago: The University of Chicago Press.

Tambiah, S. J. 1990. Magic, Science, Religion and the Scope of Rationality. Cambridge: Cambridge University Press.

Taylor, C. 2007. A Secular Age. Cambridge: Harvard University Press.

Taylor, C. 2011. "Western Secularity." In Rethinking Secularism, edited by Craig Calhoun, Mark Juergensmeyer, and Jonathan VanAntwerpen, 31-53. Oxford: Oxford University Press.

Van Der Veer, P. 2014. The Modern Spirit of Asia: The Spiritual and the Secular in China and India. Princeton: Princeton University Press.

Viveiros De Castro, E. [2013] 2002. “The Relative Native." HAU: Journal of Ethnographic Theory 3 (3): 473-502. doi:10.14318/hau3.3.032.

Wagner, R. 1981. The Invention of Culture. (Revised and Expanded Edition). Chicago: The Chicago University Press.

Watts Miller, W. 1998. “Teaching Autonomy." In Durkheim and Modern Education, edited by Geoffrey Walford, and W. S. F. Pickering, 72-91. London: Routledge. 